UDC 539.1

DOI: $10.21668 /$ health.risk/2021.1.07.eng

Research article

\title{
HEAVY METAL CONCENTRATION IN VEGETABLES AND THEIR POTENTIAL RISK FOR HUMAN HEALTH
}

\author{
A. Feseha ${ }^{1,2}$, A.K. Chaubey ${ }^{1}$, A. Abraha ${ }^{3}$ \\ ${ }^{1}$ Department of Physics, College of Natural \& Computational Sciences, Addis Ababa University, Addis Ababa, Ethiopia \\ ${ }^{2}$ Department of Physics, College of Natural \& Computational Sciences, Arba Minch University, Arba Minch, Ethiopia \\ ${ }^{3}$ Department of Physics, College of Natural and Computational Sciences, Samara University, Samara, Ethiopia
}

This study assesses heavy metal levels in the water, soil, and vegetables (swiss chard, lettuce, cabbage, collard green, tomato, green pepper, and carrot) irrigated with wastewater in Gamo, Ethiopia. The samples of soils, waters, and vegetables were randomly collected, processed, and analyzed for heavy metals using atomic absorption spectroscopy. The obtained results show that the mean concentrations of $\mathrm{Cd}$, $\mathrm{Cr}$, and $\mathrm{Ni}$ were the highest, and $\mathrm{Pb}, \mathrm{Zn}$, and $\mathrm{Cu}$ had the lowest concentration in irrigation waters. The levels of Cd in the Kulfo river area and Chamo Lake area and Cu in most of the farm soils were also found to be higher than the reference values. The study also revealed that the mean levels of Cd in most vegetables and $\mathrm{Cr}$ and $\mathrm{Pb}$ in some vegetables were higher than the maximum recommended limits set by the World Health Organization / Food and Agriculture Organization 2001. Among the vegetables, cabbage had the highest heavy metal content followed by Swiss-chard, carrot, tomato, collard green, green pepper, and lettuce. The hazard quotient obtained for $\mathrm{Cu}$, and $\mathrm{Ni}$ in all vegetable samples and $\mathrm{Cd}$ in some vegetable samples exceeded 1. It indicates that there are potential health risks to consumers. This study recommends regular monitoring over heavy metals contents in soils, waters, and foodstuffs to prevent their excessive accumulation in food chains.

Key words: heavy metals; pollution; vegetables; hazard quotient, risk assessment, safety, human health, FAAS.

Vegetables as reported by [1] are essential sources that provide people with a wide range of vital micronutrients. Several researchers observed that vegetable consumption could prevent several chronic noncommunicable diseases such as cardiovascular diseases, kidney, nervous as well as bone diseases. Vegetables also contribute substantially in providing a body with proteins, minerals, vitamins, fiber, and other nutrients which are usually in short supply in daily diets $[2,3]$. The recent trend indicates that there is an increasing awareness regarding nutritive value of vegetables to the extent that many people now prefer eating vegetables to meat [4]. Vegetables have been recognized to have some medical properties due to antioxidant and antimicrobial effects. Many of them were even documented to possess anti-diabetic, anti-inflammatory, and anti-hypertensive potential $[5,6]$.

But at the same time safety and quality of agricultural products to a great extent depends on a place where they are grown, especially in case there is a threat that toxicants, heavy metals included, can occur in the environment. Heavy metals being introduced into the environment through anthropogenic sources are a serious growing problem throughout the world [7-9]. Anthropogenic sources of heavy metal contaminants include domestic, industrial, agricultural, bush burning, fossil fuels burning, etc.

Water gets contaminated with heavy metals on certain territories practically unavoidably since there are natural reasons for it (rock

(c) Feseha A., Chaubey A.K., Abraha A., 2021

Abrham Feseha - Postgraduate student of the Department of Physical Sciences (e-mail: abrham.feseha@aau.edu.et; tel.: +251-111-239768; ORCID: https://orcid.org/0000-0001-5507-6588).

Ashok Kumar Chaubey - Academician, Doctor of Physical Sciences, Professor (e-mail: chaubeyak@aau.edu.et; tel.: +251-111-239768; ORCID: https://orcid.org/0000-0002-0536-0852).

Ataklti Abraha - Academician, Doctor of Physical Sciences, Assistance Professor (e-mail: atklt.physics@gmail.com; ORCID: https://orcid.org/0000-0001-8407-2113). 
erosion) and anthropogenic activities (industries, agriculture, and households). Wastewaters from mining, electric industry, dye works, and chemical laboratories often contain heavy metals in high concentrations including cadmium $(\mathrm{Cd})$, copper $(\mathrm{Cu})$, and lead $(\mathrm{Pb})$. Agricultural soils get contaminated with heavy metals due to irrigation with wastewaters and it is rather alerting since it can produce negative effects on people's health. A study was performed in Ghana that focused on water in irrigation systems used for growing cabbage, carrots, and lettuce that contained $\mathrm{Cd}$ and $\mathrm{Pb}$; the study revealed that $\mathrm{Cd}$ and $\mathrm{Pb}$ concentrations grew considerably together with a growth in irrigation water concentration. In most developing countries it is a usual practice to grow vegetables along rivers that flow through urban territories. Water in such rivers is often reported to be contaminated with heavy metals. An extent to which metals are absorbed by plants from water depends, among other things, on a plant itself and chemical structure of a contaminant, element concentration in soil. $\mathrm{pH}$, and interaction with other metals. Water gets contaminated with heavy metals mostly due to waste discharge from mining industry as well as from a wide range of other industries.

Heavy metals are found in soils in different chemical forms and it is closely connected to their solubility that directly depends on their mobility and biological availability. Soluble heavy metals easily penetrate plants. The highest concentrations in soils were detected for zinc $(113 \mathrm{mg} / \mathrm{kg})$, chromium $(47.8 \mathrm{mg} / \mathrm{kg})$, lead $(17.7 \mathrm{mg} / \mathrm{kg})$ and cadmium $(0.250 \mathrm{mg} / \mathrm{kg})$; they were detected on agricultural territories in Zivey, Burau, and Addis Ababa provinces. Heavy metals concentrations detected near Addis Ababa were the highest in comparison with Zivey province. It indicates that agricultural products are grown on territories where metals concentrations in soils occur due to natural reasons.

Some heavy metals such as $\mathrm{Fe}, \mathrm{Zn}, \mathrm{Cu}$, and Se are essential for people especially when they are in small quantities. However, heavy metals are non-biodegradable and therefore readily accumulate to toxic levels in biological media and produce negative effects on animals, plants, and humans when they exceed a certain threshold [9]. Other heavy metals such as $\mathrm{Pb}, \mathrm{As}, \mathrm{Cd}$, and $\mathrm{Hg}$ are toxic even in low concentrations and exposure to them results in certain health problems.

The human body can be easily contaminated by heavy metals such as $\mathrm{Ni}, \mathrm{Cd}, \mathrm{Cr}, \mathrm{Pb}$, and $\mathrm{Cu}$ through dietary exposure or exposure to the contaminated environment. Since fruits and vegetables can absorb heavy metal contents from the soil, even the same crops, fruits or vegetables, can contain minerals in different quantities depending on soils and a region where these plants are cultivated. The increased concentration of heavy metals is associated with the etiology of several diseases, especially cardiovascular, renal, and neurological disorders.

Cadmium is a non-essential element that occurs in foods and natural waters and it accumulates principally in the kidneys and liver. Cadmium causes acute and chronic poisoning, adverse effects on the kidneys, and liver, vascular and immune systems. Recently great attention has been paid to this element contents in water, soils, milk, food products and medicinal herbs and plants. Cadmium occurs on soils and plants most frequently from phosphate fertilizers, melting furnaces at nonferrous metallurgic enterprises, lead and zinc mines, discharges from industrial enterprises, and organic fuels burning.

Lead is a serious cumulative body poison that enters a body with air, water, and food and cannot be removed by washing fruits and vegetables.

Copper is an essential trace element required for proper health in a relevant quantity. Its high concentrations in fruits and vegetables can be harmful to human health and in the same way; low consumption can cause many symptoms like growth retardation, skin ailments, and gastrointestinal disorders.

Zinc is an essential element and an integral component in many coenzymes, essential for the synthesis of DNA, RNA, proteins, and insulin but toxic in high concentrations. 
People may get exposed to chromium via inhalation, drinking water consumption, or eating food containing chromium or even through skin contact. Exposure to elevated levels of chromium leads to skin irritation, ulceration, damage to circulatory and nerve tissues and it causes health problems. However, daily intake of this metal within a certain range of concentrations (up to $200 \mu \mathrm{g} /$ day) by human beings and animals is considered to be essential for carbohydrate \& lipid metabolism.

Analyzing and predicting consequences caused by pollution requires identifying and determining a number of potential risk sources, estimating a number of risk factors that come into contact with the human-environment boundaries; estimating levels of exposure via detecting routes of exposure to a target organism and quantifying health risks caused by this exposure. However, the fact that the contaminant levels exceed the permissible limits set by such regulatory agencies as the World Health Organization (WHO) does not always indicates there is a risk for human health. For this reason, the target hazard quotient (THQ) method designed by the United States Environmental Protection Agency (USEPA) for assessing potential health risks associated with long-term exposure to heavy metals was used to assess health risks in this study [9]. THQ that was equal to or greater than one $(1 \geq)$ indicated a health risk to exposed population.

Currently in Arba Minch Gamo-zone, Ethiopia there is no regulatory criterion of heavy metals in irrigation waters, soils \& vegetables. However, due to businesses' economic, industrial, and other development activities, heavy metals concentrations are increasing in irrigation waters, agricultural soils, vegetables, and crops that are grown in and outside the city. The farmlands and land spots along the river bank are intensely used in crops and vegetable production, but still, very little information is available regarding heavy metals contents in irrigation waters, soils, and vegetables. Therefore, the present investigation aims to quantify the concentration of various metals in soils and commonly grown vegetables irrigated with wastewater to calculate the daily intake rate of metals (DIR) basing on intake of particular vegetables by local population and to estimate hazards for human health related to heavy metals through the consumption of vegetables grown on four irrigational sites in Gamo, Ethiopia. The results will provide invaluable baseline data for further investigation of heavy metals accumulation in foodstuffs, thereby improving food safety and more efficient health protection for people who live on the examined territory.

Materials and methods. Arba Minch located at $6^{\circ} 2^{\prime} \mathrm{N} 37^{\circ} 33^{\prime} \mathrm{E}$ is one of a town in Gamo Gofa Zone, Southern Nations Nationalities and Peoples Region (SNNPR) regional state in Ethiopia found around $500 \mathrm{~km}$ away from Addis Ababa, Ethiopia's capital city. The town got its present name Arba Minch, meaning «40 springs» since it has 40 natural springs which are major tourist attractions (Figure). Kulfo River, Abaya Lake, and Chamo Lake are the water source for many inhabitants in the Arba Minch area for farmlands, for domestic activities, etc. The river and lakes have their source from the highlands in Gamo region which have experienced high levels of agricultural development. The farmlands where these lakes and river water were used for irrigation were selected for this study.

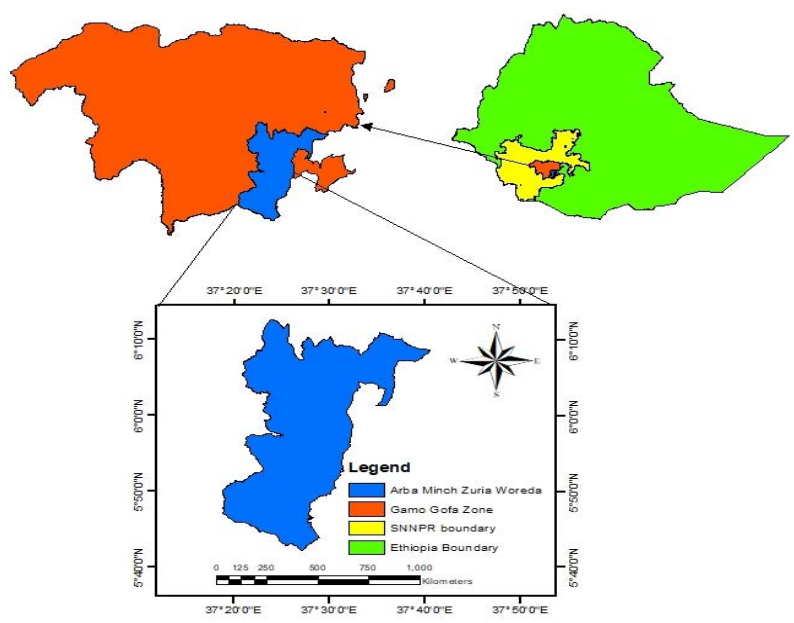

Figure 1. Location map of Arba Minch Zuriya district

Samples of soil, irrigating water, and seven commonly consumed vegetables namely, Swiss chard, lettuce, cabbage, collard green, tomato, green pepper, and carrot were collected from 
irrigational sites in Gamo, Ethiopia. All samples were randomly collected from the farmlands. Soil samples were collected at $15 \mathrm{~cm}$ depth. The collected soil and vegetable samples were put into clean polythene bags and labeled, while water samples were put in previously rinsed and dried bottles; then, all the samples were brought to the Chemistry Laboratory at the Arbaminch University (AMU) for preparation and subsequent atomic sbsorption spectroscopy analysis.

$15 \mathrm{ml}$ of a water sample was taken in a Teflon tube and then $5 \mathrm{ml} \mathrm{HNO}_{3}$ and $1 \mathrm{ml}$. $\mathrm{H}_{2} \mathrm{O}_{2}$ were added to it. The vial was closed tightly and then inserted into a single safety shield carousel installed in a microwave chamber. The mixture was heated at $120^{\circ} \mathrm{C}$ for over $3 \mathrm{hr}$ in a microwave digester. After the process was completed, the clear and colorless solution was filtered using Whatman filter paper No. 42 and diluted with deionized water to raise the volume of the solution to $50 \mathrm{~mL}$ [10]. Finally, the samples were stored in plastic bottles until analysis.

$500 \mathrm{~g}$ of a soil sample was placed in a polythene bag, dried in a microwave oven, and ground into a fine powder which was passed through a $2-\mathrm{mm}$ mesh sieve. $1 \mathrm{~g}$ of a soil sample was diluted in a tri-acid mixture of $(65 \%$ of $\mathrm{HNO}_{3}: 70 \%$ of $\mathrm{HClO}_{4}: 30 \%$ of $\mathrm{H}_{2} \mathrm{O}_{2}$ ) with a $6: 4: 1$ ratio respectively. The solution was heated to $200^{\circ} \mathrm{C}$ over $3 \mathrm{hr}$ until brown fumes ceased to emit from the solution. The solution was filtered through Whatman filter paper No. 42 and then diluted with deionized distilled water to raise the volume of the solution to $50 \mathrm{~mL}$ [10]. The prepared samples were analyzed with flame atomic absorption spectroscopy (model AA 400P, Germany) in order to determine heavy metals concentrations in them.

The vegetable samples were cut into small pieces and then dried using the oven-dry procedure at $105^{\circ} \mathrm{C}$ for $24 \mathrm{hr}$ (Memmert UF 260 plus $230 \mathrm{~V}$ Sunon model) to remove moisture. Dry samples were ground to powder and then bolted through a $1 \mathrm{~mm}$ sift. $0.5 \mathrm{~g}$ of a sample were taken in reference vessels, added with $6 \mathrm{ml}$ of $65 \% \mathrm{HNO}_{3}, 3 \mathrm{ml}$ of $70 \% \mathrm{HClO}_{4}$ and $1 \mathrm{ml}$ of $30 \% \mathrm{H}_{2} \mathrm{O}_{2}$ and then put onto a carousel installed in a microwave unit. The mixture was heated at $80{ }^{\circ} \mathrm{C}$ for over $3 \mathrm{hr}$ in a microwave digester. After the process was completed, the clear and colorless solution was filtered using Whatman filter paper No. 42 and diluted with deionized water to raise the volume of the solution up to $50 \mathrm{~mL}$ [10]. Finally, the samples were stored in plastic bottles till analysis. The samples of vegetables, soils \& waters collected from four sites in Ethiopia are illustrated in Table 1.

Table 1

Samples of vegetables, soils \& waters were taken from four sites in Ethiopia

\begin{tabular}{|c|c|c|c|c|c|}
\hline & \multirow{2}{*}{ Samples } & \multicolumn{4}{|c|}{ Waste water irrigated site } \\
\hline & & KRA & ATSHCA & ALA & CHLA \\
\hline \multirow{7}{*}{$\begin{array}{l}\frac{\infty}{0} \\
\frac{\pi}{0} \\
\stackrel{0}{0} \\
\infty \\
>0\end{array}$} & Swiss chard & $\checkmark$ & $\checkmark$ & $\checkmark$ & $\checkmark$ \\
\hline & Lettuce & $\checkmark$ & $\checkmark$ & $\checkmark$ & $\checkmark$ \\
\hline & Cabbage & $\checkmark$ & $\checkmark$ & $\checkmark$ & $\checkmark$ \\
\hline & $\begin{array}{l}\text { Collard } \\
\text { Greens }\end{array}$ & $\checkmark$ & $\checkmark$ & $\checkmark$ & $\checkmark$ \\
\hline & Tomato & $\checkmark$ & $\checkmark$ & $\checkmark$ & $\checkmark$ \\
\hline & $\begin{array}{l}\text { Green } \\
\text { pepper }\end{array}$ & $\checkmark$ & $\checkmark$ & $\checkmark$ & $\checkmark$ \\
\hline & Carrot & $\checkmark$ & $\checkmark$ & $\checkmark$ & $\checkmark$ \\
\hline \multicolumn{2}{|c|}{ Soil } & $\checkmark$ & $\checkmark$ & $\checkmark$ & $\checkmark$ \\
\hline \multicolumn{2}{|c|}{ Irrigation water } & $\checkmark$ & $\checkmark$ & $\checkmark$ & $\checkmark$ \\
\hline
\end{tabular}

$\mathrm{N}$ o t e : KRA - Kulfo river area, ATSHCA - Arbaminch textile share company area, ALA - Abaya lake area, CHLA - chamo lake area, Right mark $(\checkmark)$ indicates samples collected.

The prepared samples have analyzed for determining heavy metals concentrations in them using atomic absorption spectrometry with flame atomization, microwave oven, and dry oven (FAAS (flame atomic absorption spectroscopy) model AA 400P, Germany). Conventional auxiliary devices were applied. All the solutions were prepared using analytical chemical calibration reagents and deionized water. Graphical calibration standard solutions for all determinations were prepared by sequential dilution of conventional standards per $1,000 \mathrm{ppm}$.

All the procedures used in the present study were selected due to available data on them being successfully applied to determine heavy metals in different matrixes [11]. The instrumental operating conditions for the de- 
termination of heavy metals using FAAS are illustrated in Table 2. To provide high quality of experimental data, each sample was analyzed three times.

Table 2

Instrumental operating condition for determining heavy metals in wastewater, soil, and vegetable samples via FAAS $[12,13]$

\begin{tabular}{|c|c|c|c|c|}
\hline Element & $\begin{array}{c}\text { Wavelength } \\
(\mathrm{nm})\end{array}$ & $\begin{array}{c}\text { Lamp } \\
\text { Current } \\
(\mathrm{mA})\end{array}$ & $\begin{array}{c}\text { Slit Width } \\
(\mathrm{nm})\end{array}$ & $\begin{array}{c}\text { Flame } \\
\text { type }\end{array}$ \\
\hline $\mathrm{Cd}$ & 228.8 & 2.0 & 1.2 & $\begin{array}{c}\text { Air- } \\
\text { acetylene }\end{array}$ \\
\hline $\mathrm{Cr}$ & 357.9 & 6.0 & 0.7 & $\begin{array}{c}\text { Air- } \\
\text { acetylene }\end{array}$ \\
\hline $\mathrm{Pb}$ & 283.3 & 5.0 & 0.7 & $\begin{array}{c}\text { Air- } \\
\text { acetylene }\end{array}$ \\
\hline $\mathrm{Zn}$ & 213.9 & 5.0 & 0.7 & $\begin{array}{c}\text { Air- } \\
\text { acetylene }\end{array}$ \\
\hline $\mathrm{Cu}$ & 324.7 & 4.0 & 0.5 & $\begin{array}{c}\text { Air- } \\
\text { acetylene }\end{array}$ \\
\hline $\mathrm{Ni}$ & 232.0 & 7.0 & 0.6 & $\begin{array}{c}\text { Air- } \\
\text { acetylene }\end{array}$ \\
\hline
\end{tabular}

The procedure was validated according to the protocol guidelines on the International Conference on Harmonization [14]. Analytical grade (Merck, Germany) reagents were used in all the experimental procedures of the research study.

Metals transfer from the contaminated soil to the edible parts of the vegetables was estimated via the transfer factor (TF) formula (1) [15-17].

$$
\mathrm{TF}=\frac{C_{\text {vegetables }}}{C_{\text {soil }}}
$$

where $C_{\text {vegetables }}$ is metals concentration in vegetables $(\mathrm{mg} / \mathrm{kg})$ and $C_{\text {soil }}$ is metals concentration in soils $(\mathrm{mg} / \mathrm{kg})$. The higher is the value of $\mathrm{TF}$, the more available heavy metals are. Hence, high TF values may indicate that heavy metals are poorly retained by soils or they are too efficiently absorbed by vegetables. Low TF values mean that there is a strong bond between heavy metals and colloids in soils.

Metals mobility when they are transferred from soils into plants is a function from physical and chemical properties of soils and vegetable types. This mobility changes when influ- enced by multiple anthropogenic and environmental factors. Differences in the transfer factor calculated for different vegetables may be due to different heavy metals concentrations in soils and differences related to elements consumption by different vegetables.

High accumulation factor (AF) values may indicate a potential health risk for consumers.

Assessment of health risk caused by consuming vegetables irrigated with wastewaters on the examined territories was performed taking into account daily intake rate (DIR). DIR were calculated basing on a questionnaire $(n=400$ for each vegetable) (Table 3$)$.

Table 3

Respondents interviewed for health risk assessment of wastewater irrigated vegetable consumption on the examined territories

\begin{tabular}{|l|c|c|c|}
\hline \multirow{2}{*}{ Respondents } & \multicolumn{2}{|c|}{$\begin{array}{c}\text { Age group } \\
\text { (years old) }\end{array}$} & \multirow{2}{*}{$\begin{array}{c}\text { Total interviewed } \\
\text { persons }\end{array}$} \\
\cline { 2 - 3 } & $<16$ & $>16$ & \\
\hline Male & 95 & 135 & 230 \\
\hline Female & 76 & 94 & 170 \\
\hline Total interviews & \multicolumn{2}{|l|}{} & 400 \\
\hline
\end{tabular}

Average body weight for an adult and a child was taken as $60 \mathrm{~kg}$ and $25 \mathrm{~kg}$ accordingly.

The daily intake rate of metals through consumption of selected vegetables (Swiss chard, lettuce, cabbage, collard green, tomato, green pepper, and carrot) was calculated with the equation (2) [15-19].

$$
\mathrm{DIR}=\frac{C_{\text {metals }} \cdot D_{\text {average vegetable intake }}}{B_{\text {average weight }}}
$$

where $C_{\text {metals }}$ represents average element concentration in vegetable $(\mathrm{mg} / \mathrm{kg})$ and $D_{\text {average vegetable intake }}$ is average daily vegetable consumption or intake (kg/day-person) and $B_{\text {average weight }}$ is average body weight $(\mathrm{kg})$. From our survey, the average daily each vegetable intake for adults and children was considered to be within $0.108-0.293$ and $0.078-0.169 \mathrm{~kg} /$ (person-day) range, respectively, while the average adults and children body weights were considered to be 60 and $25 \mathrm{~kg}$, respectively. All the data are summarized in Table 4. 
Table 4

Average daily intake of each vegetable (kg/day-person)

\begin{tabular}{|l|c|c|c|c|c|c|c|c|}
\hline Vegetables & Swiss Chard & Lettuce & Cabbage & $\begin{array}{c}\text { Collard } \\
\text { Green }\end{array}$ & Tomato & $\begin{array}{c}\text { Green } \\
\text { Pepper }\end{array}$ & Carrot & Total $D_{\text {ave }}$ \\
\hline Adults & 0.227 & 0.163 & 0.246 & 0.293 & 0.231 & 0.108 & 0.187 & 1.455 \\
\hline Children & 0.113 & 0.098 & 0.169 & 0.157 & 0.128 & 0.078 & 0.103 & 0.846 \\
\hline
\end{tabular}

Hazard level for non-carcinogenic contaminants was determined by calculating a Hazard Quotient (HQ) [20]. Hazard quotient or chronic threat assessment in this study was calculated with the equation (3) of $[15,21,22]$. If a hazard quotient value is lower than one, then exposed consumers are assumed to be safe, but if it is equal to or higher than one, it is considered not safe for human health $[22,23]$.

$$
H Q=\frac{D I R}{R f D}
$$

where $D I R$ represents the daily intake rate and $R f D$ represents the reference dose of metals. The $R f D$ values for $\mathrm{Cd}, \mathrm{Pb}, \mathrm{Cr}, \mathrm{Ni}, \mathrm{Zn}$ and $\mathrm{Cu}$ are $0.001,0.004,1.5,0.02,0.3$, and $0.04 \mathrm{mg} / \mathrm{kg}$-day, respectively; these values were taken from integrated risk information system [22, 24, 25].

Hazard index $(H I)$ was developed to evaluate potential health risks for consumers that occurred due to exposure to more than one potential toxic element [25]. It was calculated by summating hazard quotients for each element in each vegetable as per the following formula (4) $[25,20]$.

$$
H I=\sum H Q
$$

We took into account one-directional effects produced on critical organs and systems by the examined heavy metals according to the matrix presented in Table 5.

The data obtained in the research work were statistically processed via calculating average values. Average values for metal concentrations in water, soil, and vegetable samples were compared by using an independent sample $t$-test. Statistics applied software, version 8.1, was used for basic descriptive statistical analysis of the data.
Table 5

Data obtained from ATSDR on effects produced by heavy metals on critical organs and systems

\begin{tabular}{|l|c|c|c|c|c|c|}
\hline $\begin{array}{l}\text { Critical } \\
\text { organs/systems }\end{array}$ & $\mathrm{Zn}$ & $\mathrm{Cd}$ & $\mathrm{Cr}$ & $\mathrm{Cu}$ & $\mathrm{Ni}$ & $\mathrm{Pb}$ \\
\hline $\begin{array}{l}\text { Central nervous } \\
\text { system }\end{array}$ & & & & & & + \\
\hline $\begin{array}{l}\text { Cardiovascular } \\
\text { system }\end{array}$ & & & & & + & \\
\hline Digestive system & & + & & & & + \\
\hline Kidneys & & & + & + & + & \\
\hline Blood & + & + & + & & & \\
\hline Development & & & & & + & + \\
\hline $\begin{array}{l}\text { Reproductive } \\
\text { system }\end{array}$ & & & & & & + \\
\hline $\begin{array}{l}\text { Hormonal } \\
\text { system }\end{array}$ & & & & & & + \\
\hline
\end{tabular}

Results and discussion. Validation results indicated that calibration curves for the various concentration ranges showed good correlation coefficients ranged between 0.9987 and 0.9999, which was higher than the required limit (0.995) for trace element analysis $[26,27]$. This showed that there was a strong correlation between concentration and absorbance indicating that the devices were properly calibrated (Table 6).

The instrumental detection limits (IDL) ranged between 0.0005 and $0.01 \mathrm{mg} / \mathrm{kg}$ and it was below the limit of detection (LOD) indicating good sensitivity of the measuring instrument used for analysis. The limit of detection (LOD) ranged from 0.075 to $0.372 \mathrm{mg} / \mathrm{kg}$. The limit of quantification (LOQ) lied within $0.227-1.127 \mathrm{mg} / \mathrm{kg}$ range and the result shows both the LOD and LOQ values were greater than the IDL; hence, the results obtained via our analysis could be reliable [28].

Recovery results were within $80-120 \%$ range and it was acceptable for metal analysis [29]. The precision of the method was expressed as 
Table 6

Validation Parameters

\begin{tabular}{|c|c|c|c|c|c|c|c|}
\hline Metals & $\begin{array}{c}\text { IDL } \\
(\mathrm{mg} / \mathrm{kg})\end{array}$ & $\begin{array}{c}\mathrm{LOD} \\
(\mathrm{mg} / \mathrm{kg})\end{array}$ & $\begin{array}{c}\text { LOQ } \\
(\mathrm{mg} / \mathrm{kg})\end{array}$ & $\begin{array}{c}\text { Regression } \\
\text { Equation }\end{array}$ & $\begin{array}{c}\text { Correlation Coef- } \\
\text { ficient }\left(R^{2}\right)\end{array}$ & Recovery (\%) & RSD (\%) \\
\hline $\mathrm{Cd}$ & 0.0005 & 0.153 & 0.465 & $y=0.1247 x-0.003$ & 0.9998 & $101.294 \pm 3.398$ & 3.355 \\
\hline $\mathrm{Cr}$ & 0.002 & 0.184 & 0.558 & $y=0.0112 x+0.002$ & 0.9997 & $98.905 \pm 3.578$ & 3.618 \\
\hline $\mathrm{Pd}$ & 0.01 & 0.372 & 1.127 & $y=0.0044 x+0.0009$ & 0.9987 & $99.436 \pm 8.495$ & 8.543 \\
\hline $\mathrm{Zn}$ & 0.0008 & 0.075 & 0.227 & $y=0.1429 x+0.0277$ & 0.9999 & $99.265 \pm 2.095$ & 2.110 \\
\hline $\mathrm{Cu}$ & 0.001 & 0.200 & 0.606 & $y=0.063 x-0.0013$ & 0.9996 & $98.273 \pm 5.608$ & 5.706 \\
\hline $\mathrm{Ni}$ & 0.002 & 0.211 & 0.638 & $y=0.0243 x+0.0019$ & 0.9996 & $98.974 \pm 4.515$ & 4.562 \\
\hline
\end{tabular}

N o t e : ${ }^{\mathrm{a}}$ Source for FAAS; ${ }^{\mathrm{b}} \mathrm{Mean} \pm \mathrm{SD}, n=7, \mathrm{SD}=$ standard deviation, $\mathrm{mg} / \mathrm{kg}$ : milligram per kilogram, RSD: relative standard deviation.

relative standard deviation (RSD) of the three replicate readings. The obtained RSD values ranged from 2.110 to $8.543 \%$, which was under the required control limits $\leq 15 \%$ [30, 31]. These results indicate that the proposed method was precise and accurate.

Average concentrations of heavy metals detected in soil, water, and vegetables samples taken on four examined territories are given in Tables 7-9.

As we can see from the Table 7, average $\mathrm{Cr}, \mathrm{Pb}, \mathrm{Zn}$, and $\mathrm{Ni}$ concentrations in soil samples from all irrigated sites were found to be lower than the recommended upper limits for soils by FAO/WHO \& USEPA [32-35]. The situation is the same with $\mathrm{Cd}$ concentration in soil samples obtained from the ATSHCA and ALA and also $\mathrm{Cu}$ concentration in soil samples obtained from the KRA and ATSHCA.

Concentration of $\mathrm{Cd}$ from KRA and CHLA farms and $\mathrm{Cu}$ concentration from ALA and CHLA irrigated sites were higher than the recommended maximum limit for soil by FAO/WHO \& USEPA [36-40].

The concentrations of $\mathrm{Zn}, \mathrm{Pb}$, and $\mathrm{Cu}$ in the wastewater samples that were detected on all irrigational sites were lower than the recommended maximum level for irrigation water set by USEPA \& FAO/WHO. But at the same time, we detected relatively high concentrations of $\mathrm{Cd}, \mathrm{Cr}$, and $\mathrm{Ni}$ in wastewaters used for irrigation on all the examined territories and these concentrations were higher than maximum recommended levels for these metals. The results obtained show that the wastewater samples are substantially contaminated with these heavy metals. Therefore, attention should be focused on regular monitoring and control of wastewater used for irrigation.

Results obtained via quantifying metals in vegetables are shown in Table 8 . Cd concentration in vegetables grown on the examined territories varied from $0.18 \mathrm{mg} / \mathrm{kg}$ (lettuce, ALA) to $0.45 \mathrm{mg} / \mathrm{kg}$ (Swiss chard, KRA) [41, 42].

Table 7

Average concentration of heavy metals found in soil farmlands and irrigation water

\begin{tabular}{|c|c|c|c|c|c|c|c|c|c|c|}
\hline \multirow{2}{*}{$\begin{array}{c}\text { Heavy } \\
\text { metals }\end{array}$} & \multicolumn{2}{|c|}{ KRA } & \multicolumn{2}{c|}{ ATSHCA } & \multicolumn{2}{c|}{ ALA } & \multicolumn{2}{c|}{ CHLA } & \multicolumn{2}{c|}{$\begin{array}{c}\text { Guidelines for max. } \\
\text { levels in }\end{array}$} \\
\cline { 2 - 13 } & $\begin{array}{c}\text { water } \\
(\mathrm{mg} / \mathrm{L})\end{array}$ & $\begin{array}{c}\text { Soil } \\
(\mathrm{mg} / \mathrm{kg})\end{array}$ & $\begin{array}{c}\text { water } \\
(\mathrm{mg} / \mathrm{L})\end{array}$ & $\begin{array}{c}\text { Soil } \\
(\mathrm{mg} / \mathrm{kg})\end{array}$ & $\begin{array}{c}\text { water } \\
(\mathrm{mg} / \mathrm{L})\end{array}$ & $\begin{array}{c}\text { Soil } \\
(\mathrm{mg} / \mathrm{kg})\end{array}$ & $\begin{array}{c}\text { water } \\
(\mathrm{mg} / \mathrm{L})\end{array}$ & $\begin{array}{c}\text { Soil } \\
(\mathrm{mg} / \mathrm{kg})\end{array}$ & $\begin{array}{c}\text { water } \\
(\mathrm{mg} / \mathrm{L})\end{array}$ & $\begin{array}{c}\text { Soil } \\
(\mathrm{mg} / \mathrm{kg})\end{array}$ \\
\hline $\mathrm{Cd}$ & 0.2605 & 3.9096 & 0.185 & 1.8261 & 0.1634 & 1.7512 & 0.245 & 3.2113 & 0.01 & 3 \\
\hline $\mathrm{Cr}$ & 0.8402 & 19.897 & 0.2567 & 13.0664 & 0.4738 & 16.2893 & 0.6701 & 8.2187 & 0.1 & 50 \\
\hline $\mathrm{Pb}$ & 0.0094 & 13.8313 & 0.0038 & 10.4406 & 0.0024 & 12.5333 & 0.0056 & 11.7341 & $0.015^{\mathrm{c}}$ & 100 \\
\hline $\mathrm{Zn}$ & 0.3488 & 52.2735 & 1.3954 & 42.5626 & 0.1461 & 53.0685 & 0.0770 & 68.5274 & 2 & 300 \\
\hline $\mathrm{Cu}$ & 0.4643 & 48.8125 & 0.6743 & 40.8878 & 1.2759 & 57.1213 & 0.366 & 51.2222 & $2^{\mathrm{d}}$ & $50^{\mathrm{c}}$ \\
\hline $\mathrm{Ni}$ & 0.8767 & 42.1764 & 0.5609 & 31.3822 & 0.3953 & 19.5129 & 0.6811 & 31.3866 & $0.07^{\mathrm{d}}$ & $80^{\mathrm{c}}$ \\
\hline
\end{tabular}

N o t e : ${ }^{a}$ WHO/FAO (2007), ${ }^{b} W H O / F A O ~(2001),{ }^{c} U S E P A ~(2010),{ }^{d} W H O$ (2008), mg/kg: milligram per kilogram, $\mathrm{mg} / \mathrm{L}$ : milligram per litter. 
Table 8

Concentration of heavy metals $(\mathrm{mg} / \mathrm{kg})$ in vegetable samples in four sites of Ethiopia

\begin{tabular}{|c|c|c|c|c|c|c|c|c|c|c|c|c|}
\hline \multirow{2}{*}{ Vegetables } & \multicolumn{6}{|c|}{ Heavy metals } & \multicolumn{6}{|c|}{ Heavy metals } \\
\hline & $\mathrm{Cd}$ & $\mathrm{Cr}$ & $\mathrm{Pb}$ & $\mathrm{Zn}$ & $\mathrm{Cu}$ & $\mathrm{Ni}$ & $\mathrm{Cd}$ & $\mathrm{Cr}$ & $\mathrm{Pb}$ & $\mathrm{Zn}$ & $\mathrm{Cu}$ & $\mathrm{Ni}$ \\
\hline Study area & \multicolumn{6}{|c|}{ KRA } & \multicolumn{6}{|c|}{ ATSHCA } \\
\hline Swiss Chard & $\frac{0,4}{524}$ & $\frac{1,4}{062}$ & $\frac{0,4}{564}$ & $\frac{27,2}{354}$ & $\frac{11,2}{354}$ & $\frac{13,8}{213}$ & $\frac{0,3}{313}$ & $\frac{1,1}{245}$ & $\frac{0,1}{987}$ & $\frac{23,4}{859}$ & $\frac{9,5}{894}$ & $\frac{9,4}{152}$ \\
\hline Lettuce & $\frac{0,2}{537}$ & $\frac{1,8}{213}$ & $\frac{0,3}{125}$ & $\frac{22,4}{562}$ & $\frac{16,4}{235}$ & $\frac{17,7}{014}$ & $\frac{0,1}{897}$ & $\frac{1,4}{526}$ & $\frac{0,1}{595}$ & $\frac{18,5}{642}$ & $\frac{13,8}{976}$ & $\frac{15,8}{631}$ \\
\hline Cabbage & $\frac{0,4}{185}$ & $\frac{2,7}{801}$ & $\frac{0,4}{562}$ & $\frac{14,2}{563}$ & $\frac{16,5}{426}$ & $\begin{array}{l}19,8 \\
916 \\
\end{array}$ & $\frac{0,3}{281}$ & $\frac{2,8}{456}$ & $\frac{0,2}{895}$ & $\frac{10,4}{586}$ & $\frac{14,5}{642}$ & $\frac{18,6}{542}$ \\
\hline Collard Green & $\frac{0,2}{304}$ & $\frac{2,9}{945}$ & $\frac{0,2}{901}$ & $\frac{10,4}{568}$ & $\frac{13,9}{648}$ & $\frac{24,9}{745}$ & $\frac{0,1}{887}$ & $\frac{2,7}{589}$ & $\frac{0,1}{693}$ & $\frac{8,5}{642}$ & $\frac{9,5}{689}$ & $\frac{23,3}{456}$ \\
\hline Tomato & $\frac{0,4}{324}$ & $\frac{1,8}{452}$ & $\frac{0,2}{812}$ & $\frac{13,6}{548}$ & $\frac{24,2}{345}$ & $\frac{26,8}{945}$ & $\frac{0,2}{791}$ & $\frac{1,5}{243}$ & $\frac{0,1}{623}$ & $\frac{10,2}{365}$ & $\frac{19,5}{642}$ & $\frac{24,4}{538}$ \\
\hline Green Pe & $\frac{0,2}{394}$ & $\frac{1,9}{452}$ & $\frac{0,2}{945}$ & $\frac{9,9}{865}$ & $\frac{21,4}{563}$ & $\frac{21,8}{916}$ & $\frac{0,1}{714}$ & $\frac{1,5}{624}$ & $\frac{0,}{91}$ & $\frac{5,4}{568}$ & $\frac{16,5}{894}$ & $\frac{20,6}{542}$ \\
\hline Carrot & $\frac{0,3}{515}$ & $\frac{2,0}{145}$ & $\frac{0,3}{912}$ & $\frac{12,4}{568}$ & $\frac{25,2}{345}$ & $\frac{25,7}{865}$ & $\frac{0,2}{988}$ & $\frac{1,7}{451}$ & $\frac{0,3}{056}$ & $\frac{9,4}{758}$ & $\frac{20,5}{642}$ & $\frac{21,5}{917}$ \\
\hline FAO/WHO & 0,200 & 2,3 & 0,3 & 99,4 & 73,3 & 67 & 0,2 & 2,3 & 0,3 & 99,4 & 73,3 & 67 \\
\hline Study area & \multicolumn{6}{|c|}{ ALA } & \multicolumn{6}{|c|}{ CHLA } \\
\hline Swiss Chard & $\underline{0,3}$ & $\frac{1,2}{345}$ & $\frac{0,2}{956}$ & $\frac{28,3}{793}$ & $\frac{11,5}{564}$ & $\frac{5,3}{914}$ & $\frac{0,4}{194}$ & $\frac{1,0}{292}$ & $\frac{0,3}{477}$ & $\frac{31,4}{526}$ & $\frac{9,9}{524}$ & $\frac{11,3}{121}$ \\
\hline Lettuce & $\frac{0,1}{797}$ & $\frac{1,5}{462}$ & $\frac{0,1}{895}$ & $\frac{24,3}{427}$ & $\frac{18,5}{462}$ & $\frac{9,8}{756}$ & $\frac{0,2}{165}$ & $\frac{1,6}{271}$ & $\frac{0,3}{9}$ & $\frac{27,4}{589}$ & $\frac{17,4}{371}$ & $\frac{16,8}{123}$ \\
\hline Cabbage & $\frac{0,2}{973}$ & $\frac{2,0}{461}$ & $\frac{0,3}{125}$ & $\frac{16,4}{24}$ & $\frac{20,6}{542}$ & $\frac{11,9}{517}$ & $\frac{0,3}{685}$ & $\frac{2,1}{686}$ & $\frac{0,4}{218}$ & $\frac{21,5}{643}$ & $\frac{18,4}{682}$ & $\frac{17,9}{453}$ \\
\hline Collard Green & $\frac{0,1}{91}$ & $\frac{2,2}{451}$ & $\frac{0,1}{885}$ & $\frac{12,2}{014}$ & $\frac{16,2}{457}$ & $\frac{17,8}{501}$ & $\frac{0,2}{155}$ & $\frac{2,6}{527}$ & $\frac{0,2}{189}$ & $\frac{16,8}{956}$ & $\frac{14,3}{566}$ & $\frac{22,7}{254}$ \\
\hline Tomato & $\frac{0,3}{152}$ & $\frac{1,4}{452}$ & $\frac{0,1}{812}$ & $\frac{15,0}{882}$ & $\frac{32,4}{568}$ & $\frac{15,3}{968}$ & $\frac{0,4}{57}$ & $\frac{1,6}{977}$ & $\frac{0,2}{101}$ & $\frac{19,5}{641}$ & $\frac{26,3}{741}$ & $\frac{25,8}{745}$ \\
\hline Green Pepper & $\frac{0,1}{885}$ & $\frac{1,7}{854}$ & $\frac{0,2}{282}$ & $\frac{10,6}{628}$ & $\frac{29,5}{463}$ & $\frac{16,7}{969}$ & $\frac{0,2}{51}$ & $\frac{1,6}{362}$ & $\frac{0,2}{586}$ & $\frac{14,5}{623}$ & $\frac{23,1}{016}$ & $\frac{19,9}{453}$ \\
\hline Carrot & $\frac{0,2}{92}$ & $\frac{1,6}{123}$ & $\frac{0,3}{156}$ & $\frac{14,5}{447}$ & $\frac{31,4}{568}$ & $\frac{15,8}{259}$ & $\frac{0,3}{421}$ & $\frac{1,9}{557}$ & $\frac{0,3}{524}$ & $\frac{17,5}{659}$ & $\frac{26,0}{377}$ & $\frac{23,6}{895}$ \\
\hline FAO/WHO (2001) & 0,2 & 2,3 & 0,3 & 99,4 & 73,3 & 67 & 0,2 & 2,3 & 0,3 & 99,4 & 73,3 & 67 \\
\hline
\end{tabular}

Average concentration of heavy metals $(\mathrm{mg} / \mathrm{kg})$ found in vegetables from all farms

\begin{tabular}{|c|c|c|c|c|c|c|c|c|}
\hline $\begin{array}{c}\text { Heavy } \\
\text { Metals }\end{array}$ & $\begin{array}{c}\text { Swiss } \\
\text { Chard }\end{array}$ & Lettuce & Cabbage & $\begin{array}{c}\text { Collard } \\
\text { Green }\end{array}$ & Tomato & $\begin{array}{c}\text { Green } \\
\text { Pepper }\end{array}$ & Carrot & $\begin{array}{c}\text { Guideline Value } \\
(\mathrm{mg} / \mathrm{kg})^{\mathrm{a}}\end{array}$ \\
\hline $\mathrm{Cd}$ & 0.38 & 0.21 & 0.35 & 0.21 & 0.36 & 0.20 & 0.32 & 0.2 \\
\hline $\mathrm{Cr}$ & 1.20 & 1.61 & 2.46 & 2.66 & 1.63 & 1.73 & 1.83 & 2.3 \\
\hline $\mathrm{Pb}$ & 0.32 & 0.24 & 0.37 & 0.22 & 0.21 & 0.24 & 0.34 & 0.3 \\
\hline $\mathrm{Zn}$ & 27.64 & 23.21 & 15.67 & 12.03 & 14.64 & 10.17 & 13.51 & 99.4 \\
\hline $\mathrm{Cu}$ & 10.58 & 16.58 & 17.56 & 13.53 & 25.66 & 22.67 & 25.82 & 73.3 \\
\hline $\mathrm{Ni}$ & 9.99 & 15.06 & 17.11 & 22.22 & 23.15 & 19.82 & 21.72 & 67 \\
\hline
\end{tabular}

$\mathrm{N}$ o t e : ${ }^{a}$ FAO/WHO-codex alimentarius commission (2001).

Cd concentrations were not significantly high in Lettuce, Collard Green, and Green Pepper and didn't differ greatly on the examined territories [43-45]. However, Cd concentrations detected in Swiss chard, Cabbage, to- mato, and carrot mostly from KRA and CHLA sites were higher than the permissibility level set by FAO/WHO. Among the sampling sites, the samples from the KRA site contained the highest $\mathrm{Cd}$ concentration which might be at- 
tributed to the sewage sludge discharge from the cement processing, metal manufacturing, stone crushing machine, and industrial waste from textile which dispose its wastes directly into the river [46, 47].

The concentration of $\mathrm{Cr}$ was observed to be the highest for collard green samples $(2.99 \mathrm{mg} / \mathrm{kg})$ from KRA. The concentrations of $\mathrm{Cr}$ detected in cabbage and collard green of the vegetables analyzed from KRA and ATSHCA sites and collard green from CHLA site were higher than the limit levels in food by FAO/WHO guidelines. Among the investigated vegetables, cabbage and collard green were found to be more Cr-loaded than other vegetables. High concentrations of this heavy metal were detected in vegetables from KRA, ATSHCA, and CHLA sites which might be due to sewage sludge discharged to the environment from metal production, cement production, textile production, and stone crashing sites or due to pollution from agronomic practices [48].

The $\mathrm{Pb}$ content was the highest in Swiss chard $(0.46 \mathrm{mg} / \mathrm{kg})$ and cabbage $(0.46 \mathrm{mg} / \mathrm{kg})$ collected on KRA farms and the lowest in lettuce $(0.16 \mathrm{mg} / \mathrm{kg})$ collected on ATSHCA farms. The $\mathrm{Pb}$ content in all of the vegetables from all farms, except Swiss chard and cabbage from KRA farms were found to be within the safe limit stated by FAO/WHO [49].

The highest concentrations of $\mathrm{Cu}$ were in tomato $(32.46 \mathrm{mg} / \mathrm{kg})$ follow by carrot $(31.46 \mathrm{mg} / \mathrm{kg})$ and green pepper $(29.55 \mathrm{mg} / \mathrm{kg})$ from ALA while the lowest $\mathrm{Cu}$ concentration was detected for collard green $(9.57 \mathrm{mg} / \mathrm{kg})$ from ATSHCA farms. Similarly, the highest levels of $\mathrm{Ni}$ were in tomato $(26.89 \mathrm{mg} / \mathrm{kg})$ from KRA while the lowest one was detected for Swiss chard $(5.39 \mathrm{mg} / \mathrm{kg}$ ) from ALA farms. The $\mathrm{Cu}$ and $\mathrm{Ni}$ content in all of the vegetable samples from all farms were found to be within the safe limit stated by FAO/WHO which is $73.3 \mathrm{mg} / \mathrm{kg}$ and $67 \mathrm{mg} / \mathrm{kg}$ respectively [50].

The results shown in Table 7 contain average concentration of zinc in all vegetable samples. CHLA had the highest concentration of $31.45 \mathrm{mg} / \mathrm{kg}$ in Swiss chard followed by $28.38 \mathrm{mg} / \mathrm{kg}$ in Swiss chard from the ALA site while the lowest concentration was obtained from the ATSHCA site with $5.46 \mathrm{mg} / \mathrm{kg}$ in green pepper [51]. This indicates that zinc was contained in all samples in concentrations that were within the stipulated limit stated by $\mathrm{FAO} / \mathrm{WHO}$ which is $99.40 \mathrm{mg} / \mathrm{kg}$.

All the obtained data allowed estimating transfer factor (TF) for various heavy metals transfer from soils into vegetables. The results are given in Table 10.

Swiss chard has the highest transfer factor values for $\mathrm{Zn}(0.52)$ followed by $\mathrm{Ni}$ (0.32). Lettuce has the highest transfer factor values for $\mathrm{Ni}(0.49)$ followed by $\mathrm{Zn}(0.43)$ [52]. As for the other vegetables, the highest $\mathrm{TF}$ values were detected for $\mathrm{Ni}$ (from 0.56 to 0.76 ) and $\mathrm{Cu}$ (from 0.27 to 0.52 ). Overall, $\mathrm{TF}$ values for heavy metals in the examined vegetable samples were in the following order:

$$
\mathrm{Ni}>\mathrm{Cu}>\mathrm{Zn}>\mathrm{Cr}>\mathrm{Cd}>\mathrm{Pb} .
$$

The highest TF values were found to be 0.76 and 0.52 for $\mathrm{Ni}$ and $\mathrm{Zn}$ respectively. These might be due to the higher mobility of these heavy metals together with natural occurrence in soil and their lower retention in soil than other toxic elements [53,54].

Table 10

Transfer Factor (TF) of heavy metals from soil to vegetables

\begin{tabular}{|c|c|c|c|c|c|c|c|c|}
\hline $\begin{array}{c}\text { Heavy } \\
\text { metals }\end{array}$ & $\begin{array}{c}\text { Swiss } \\
\text { Chard }\end{array}$ & Lettuce & Cabbage & $\begin{array}{c}\text { Collard } \\
\text { Green }\end{array}$ & Tomato & $\begin{array}{c}\text { Green } \\
\text { Pepper }\end{array}$ & Carrot & Average TF \\
\hline $\mathrm{Cd}$ & 0.12 & 0.08 & 0.12 & 0.08 & 0.12 & 0.08 & 0.13 & 0.104 \\
\hline $\mathrm{Cr}$ & 0.09 & 0.12 & 0.19 & 0.21 & 0.13 & 0.13 & 0.14 & 0.14 \\
\hline $\mathrm{Pb}$ & 0.03 & 0.02 & 0.03 & 0.02 & 0.02 & 0.02 & 0.03 & 0.024 \\
\hline $\mathrm{Zn}$ & 0.52 & 0.43 & 0.29 & 0.22 & 0.27 & 0.18 & 0.25 & 0.31 \\
\hline $\mathrm{Cu}$ & 0.22 & 0.34 & 0.35 & 0.27 & 0.51 & 0.45 & 0.52 & 0.38 \\
\hline $\mathrm{Ni}$ & 0.32 & 0.49 & 0.56 & 0.74 & 0.76 & 0.67 & 0.72 & 0.61 \\
\hline
\end{tabular}


We combined data on metals concentrations in vegetables with data on daily intake rate for each product; it allowed us to calculate daily intake of heavy metals into a body [55] (Table 11).

Daily intakes gave grounds for determining hazard quotients (Table 12). As we can see form these data, daily intakes of $\mathrm{Cd}$, $\mathrm{Cu}$, and $\mathrm{Ni}$ were higher than reference doses (RfD) recommended by USEPA and FAO/WHO both children and adults [24, 56]. The values of $H Q$ were less than 1.0 for $\mathrm{Cr}, \mathrm{Pb}$, and $\mathrm{Zn}$ in all tested vegetables and $\mathrm{Cd}$ in lettuce and green pepper for both adults and children, thus indicating a risk was insignificant.
The highest hazard (HQ) quotients were revealed for Swiss chard, tomato, and cabbage for both adults and children. Therefore, consumption of Swiss chard, tomato, and cabbage grown on the examined territories can cause high health risks.

Hazard quotients were used as a basis for estimating hazard indexes that showed probability of functional disorders in specific organs and systems due to toxic elements prodding similar effects on them [57]. In the present study it was revealed (Table 13) that the highest health risks for people who daily consumed vegetables grown on the examined irrigated sites were related to functional disorders in the kidneys, cardiovascular system and overall development [58].

Table 11

Average daily intake of Heavy metals through consumption of vegetables ( $\mathrm{mg} / \mathrm{kg}$-day)

\begin{tabular}{|c|c|c|c|c|c|c|c|c|c|c|c|}
\hline $\begin{array}{l}\text { Heavy } \\
\text { metals }\end{array}$ & Individual & $\begin{array}{l}\text { Swiss } \\
\text { Chard }\end{array}$ & Lettuce & Cabbage & $\begin{array}{c}\text { Collard } \\
\text { Green }\end{array}$ & Tomato & $\begin{array}{l}\text { Green } \\
\text { Pepper }\end{array}$ & Carrot & $\begin{array}{c}\text { Average } \\
\text { DIR }\end{array}$ & $\begin{array}{l}\text { Sum } \\
\text { DIR }\end{array}$ & $\mathrm{RfD}$ \\
\hline \multirow{2}{*}{$\mathrm{Cd}$} & Adults & 0.0022 & 0012 & 0.0020 & 0.0012 & 0021 & 0.0012 & 001 & 0.0017 & 0.0072 & \multirow{2}{*}{0.001} \\
\hline & Children & 0.0035 & 0.0020 & 0.0033 & 0.0020 & 0.00 & 0.0019 & 00 & $\overline{0.002}$ & 0.01 & \\
\hline \multirow{2}{*}{$\mathrm{Cr}$} & Adults & 0.0070 & 0.0093 & D143 & 0.0154 & 0095 & 0100 & 6 & 0.01 & 0.04 & \multirow{2}{*}{1.5} \\
\hline & Children & 0.0112 & 0.015 & 0.0229 & 0.0248 & 0.0152 & 0.0161 & .0171 & 0.0175 & 0.0662 & \\
\hline \multirow{2}{*}{$\mathrm{Pl}$} & dults & 0.0019 & 0.0014 & 0022 & 0.0013 & 0.0012 & 0.0014 & 002 & 0.0016 & 0.0068 & \multirow{2}{*}{0.00} \\
\hline & Children & 0.003 & 0.0022 & 0.0035 & 0.0021 & 0.002 & 0.0022 & .0032 & 0.0026 & 0.0096 & \\
\hline & dults & 1603 & 346 & 0909 & 0.0698 & 0 & 0.0590 & 34 & 0.0968 & 0.4072 & \multirow{2}{*}{0.3} \\
\hline & Children & 0.2576 & 0.2163 & 0.1460 & 0.1121 & 0.1364 & 0.0948 & 0.1259 & 0.1556 & 0.5596 & \\
\hline \multirow{2}{*}{$\mathrm{Cu}$} & ults & 0.0614 & 0.0962 & 0.1019 & 0.0785 & 0.1488 & 0.1315 & 0.1498 & 0.1097 & 0.4432 & \multirow{2}{*}{0.04} \\
\hline & Children & 0.0986 & 0.1545 & 0.1637 & 0.1261 & 0.2391 & 0.2113 & 0.2406 & 0.1763 & 0.625 & \\
\hline & & 0.0579 & 0.0874 & 0.0992 & 0.1289 & 0.1343 & 0.1150 & 0.1260 & 0.1069 & 0.4499 & \multirow{2}{*}{0.02} \\
\hline & Children & 0.0931 & 0.1404 & 0.1595 & 0.2071 & 0.2158 & 0.1847 & 0.2024 & 0.1719 & 0.6293 & \\
\hline
\end{tabular}

Table 12

Hazard Quotient of Heavy metals via intake of vegetables from wastewater irrigated farms

\begin{tabular}{|c|c|c|c|c|c|c|c|c|}
\hline $\begin{array}{c}\text { Heavy } \\
\text { metals }\end{array}$ & Individual & Swiss Chard & Lettuce & Cabbage & $\begin{array}{c}\text { Collard } \\
\text { Green }\end{array}$ & Tomato & $\begin{array}{c}\text { Green } \\
\text { Pepper }\end{array}$ & Carrot \\
\hline \multirow{2}{*}{$\mathrm{Cd}$} & Adults & 2.204 & 1.218 & 2.03 & 1.218 & 2.088 & 1.16 & 1.856 \\
\cline { 2 - 9 } & Children & 3.542 & 1.957 & 3.262 & 1.957 & 3.355 & 1.864 & 2.982 \\
\hline \multirow{2}{*}{$\mathrm{Cr}$} & Adults & 0.005 & 0.006 & 0.010 & 0.010 & 0.006 & 0.007 & 0.007 \\
\cline { 2 - 8 } & Children & 0.008 & 0.010 & 0.015 & 0.017 & 0.010 & 0.011 & 0.011 \\
\hline \multirow{2}{*}{$\mathrm{Pb}$} & Adults & 0.464 & 0.348 & 0.537 & 0.319 & 0.305 & 0.348 & 0.493 \\
\cline { 2 - 9 } & Children & 0.746 & 0.559 & 0.862 & 0.513 & 0.489 & 0.559 & 0.792 \\
\hline \multirow{2}{*}{$\mathrm{Zn}$} & Adults & 0.534 & 0.449 & 0.303 & 0.233 & 0.283 & 0.197 & 0.261 \\
\cline { 2 - 9 } & Children & 0.859 & 0.721 & 0.487 & 0.374 & 0.455 & 0.316 & 0.420 \\
\hline \multirow{2}{*}{$\mathrm{Cu}$} & Adults & 1.534 & 2.404 & 2.546 & 1.962 & 3.721 & 3.287 & 3.744 \\
\cline { 2 - 8 } & Children & 2.465 & 3.863 & 4.092 & 3.153 & 5.979 & 5.282 & 6.016 \\
\hline \multirow{2}{*}{$\mathrm{Ni}$} & Adults & 2.897 & 4.367 & 4.962 & 6.444 & 6.714 & 5.748 & 6.299 \\
\cline { 2 - 8 } & Children & 4.655 & 7.018 & 7.973 & 10.355 & 10.788 & 9.236 & 10.122 \\
\hline
\end{tabular}


Table 13

Hazard Index of heavy metals that affect the same target organs and systems

\begin{tabular}{|c|c|c|c|c|c|c|c|c|c|}
\hline \multirow{2}{*}{$\begin{array}{c}\text { Critical } \\
\text { organs/systems }\end{array}$} & \multirow{2}{*}{ Group } & \multirow{2}{*}{$\mathrm{HI}_{\text {макс }}$} & \multirow{2}{*}{$\mathrm{HI}_{\text {средн }}$} & \multicolumn{6}{|c|}{ Contribution made by specific metals into risks, $\%$} \\
\hline & & & & $\mathrm{Zn}$ & $\mathrm{Cd}$ & $\mathrm{Cr}$ & $\mathrm{Cu}$ & $\mathrm{Ni}$ & $\mathrm{Pb}$ \\
\hline \multirow{2}{*}{ Central nervous system } & adults & 1.7 & 0.24 & & & & & & 100 \\
\hline & children & 2.4 & 0.34 & & & & & & 100 \\
\hline \multirow{2}{*}{ Cardiovascular system } & adults & 22.5 & 3.21 & & & & & 100 & \\
\hline & children & 31.5 & 4.50 & & & & & 100 & \\
\hline \multirow{2}{*}{ Digestive system } & adults & 8.9 & 1.27 & & 80.90 & & & & 9.10 \\
\hline & children & 12.5 & 1.78 & & 80.90 & & & & 9.10 \\
\hline \multirow{2}{*}{ Kidneys } & adults & 33.61 & 4.79 & & & 0.09 & 32.97 & 66.94 & \\
\hline & children & 47.14 & 6.74 & & & 0.08 & 33.16 & 66.76 & \\
\hline \multirow{2}{*}{ Blood: } & adults & 14.11 & 1.23 & 16.01 & 83.63 & 0.36 & & & \\
\hline & children & 22.81 & 1.71 & 15.91 & 83.73 & 0.36 & & & \\
\hline \multirow{2}{*}{ Development } & adults & 40.29 & 3.46 & & & & & 92.93 & 7.07 \\
\hline & children & 64.70 & 4.84 & & & & & 92.97 & 7.03 \\
\hline \multirow{2}{*}{ Reproductive system } & adults & 1.7 & 0.24 & & & & & & 100 \\
\hline & children & 2.4 & 0.34 & & & & & & 100 \\
\hline
\end{tabular}

Conclusion. Results obtained in the present study allow concluding that consumption of vegetables irrigated with wastewaters results in unacceptable health risks, both for adults and children. The authors suggest regular monitoring over heavy metals contents in soils, irrigation water, and food products as it will allow avoiding substantial heavy metals accumulation in food chains and therefore health risks will be reduced.

Results obtained in the present study can become a stimulus for ecologists, managers, and public healthcare experts in their activities aimed at informing people about hazards related to consuming vegetables that are grown on contaminated territories; it can lead to reduction in health risks.

Acknowledgements. The authors would like to thank the physics department of Addis Ababa University $(A A U)$ and the chemistry department of Arba Minch University (AMU) for laboratory facilities.

Funding. In addition the authors would like to thank the AAU and AMU for the research grant support.

Conflict of interests. The authors declare no conflict interest concerning this publication.

\section{References}

1. Agency for Research on Cancer (IARC). Fruit and vegetables. Lyon, International Agency for Research on Cancer Publ., 2003, 24 p.

2. Delibacak S., Elmaci O.L., Secer M., Bodur A. Trace element and heavy metal concentrations in fruits \&vegetables of the Gediz River region. International Journal of Water, 2002, vol. 2, no. 2-3, pp. 196-211.

3. Fasuyi O.A. Nutritional potentials of some tropical vegetable leaf meals: Chemical characterization and functional properties. African Journal of Biotechnology, 2006, vol. 5, no. 1, pp. 49-53.

4. Orech F.O., Akenga T., Ochora J., Friis H., Aagaard H. Potential toxicity of some traditional leafy vegetables consumed in Nyang'oma Division, Western Kenya. African Journal for Food Agriculture and Nutritional Development, 2005, vol. 5, no. 1, pp. 1-14.

5. Okeno J.A., Chebet D.K., Mathenge P.W. Status of indigenous vegetables in Kenya. Acta Hort, 2003, vol. 621, no. 9, pp. 95-100. DOI: 10.17660/ActaHortic.2003.621.10

6. Smith F.I., Eyzaguirre P. African leafy vegetables: Their role in the world health organization's global fruit and vegetables initiatives. African Journal for Food Agriculture Nutritional Development, 2007, no. 7, pp. 1-9.

7. Qu C., Ma Z., Yang J., Liu Y., Bi J., Huang L. Human Exposure Pathways of Heavy Metal in a Lead-Zinc Mining Area. Heavy Metal Contamination of Water and Soil: Analysis, assessment, and remediation strategies, 2014, pp. 129-156. 
8. Tchounwou P.B., Yedjou C.G., Patlolla A.K., Sutton D.J. Heavy metal toxicity and the environment. Experiential Supplementum, 2012, no. 101, pp. 133-164. DOI: 10.1007/978-3-7643-8340-4_6

9. Highlights of the Exposure factors Handbook (Final Report). National Center for Environmental Assessment Office of Research and Development U.S. Environmental Protection Agency, 2011, 72 p.

10. Method 3005A. Acid digestion of water for total recoverable or dissolved metals for analysis by FLAA or ICP-Spectroscopy. Washington, DC: Environmental Protection Agency (EPA) Publ., $1998,5 \mathrm{p}$.

11. Helaluddin A.B.M., Reem S.K., Mohamed A., Syed A.A. Main Analytical Techniques Used for Elemental Analysis in Various Matrices. Tropical Journal of Pharmaceutical Research, 2016, vol. 15 , no. 2, pp. 427-434. DOI: 10.4314/tjpr.v15i2.29

12. Dagne B.B. Levels of Some Toxic Heavy Metals in Selected Vegetables, Soil and wastewater Around Eastern Industry Zone, Central Ethiopia. MSc Graduate project. Haramaya, Haramaya University Publ., 2017, 6 p.

13. Deribachew B., Made M., Nigussie-Dechassa R., Abi M.T. Selected heavy metals in some vegetables produced through wastewater irrigation and their toxicological implications in eastern Ethiopia. African Journal of Food, Agriculture, Nutrition, and Development, 2015, vol. 15, no. 70, pp. 10013.

14. International Conference on Harmonization (ICH). Validation of Analytical Procedures: Text and Methodology. ICH, 1994. Available at: http://www.ich.org/fileadmin/Public/Web_Site/ICH_Products/Guidelines/Quality/Q2_R1/Step4/Q2_R1_Guideline (19.02.2021).

15. Chary N.S., Kamala C.T., Raj D.S. Assessing the risk of heavy metals from consuming food grown on sewage irrigated soils and food chain transfer. Ecotoxicology Environmental Safety, 2008, vol. 69, no. 3, pp. 513-524. DOI: 10.1016/j.ecoenv.2007.04.013

16. Cui Y., Zhu Y., Zhai R., Huang Y., Qui Y., Liang L. Transfer of metals from near a smelter in Nanning, China. Environmental International Journal, 2004, vol. 30, no. 6, pp. 785-791. DOI: 10.1016/j.envint.2004.01.003

17. Khan K., Lu Y., Khan H., Ishtiaq M., Khan S., Waqas M., Wei L., Wang T. Heavy metals in agricultural soils and crops and their health risks in Swat District, northern Pakistan. Food and Chemical Toxicology, no. 58, pp. 449-458. DOI: 10.1016/j.fct.2013.05.014

18. Orisakwe O.E., Nduka J.K., Amadi C.N., Dike D.O., Bede O. Heavy metal health risk assessment for population via consumption of food crops and fruits in Owerri, South Eastern, Nigeria. Chemistry Central Journal, 2012, vol. 1, no. 6 (1), pp. 77. DOI: 10.1186/1752-153X-6-77

19. Aschale M., Sileshi Y., Kelly-Quinn M. Health risk assessment of potentially toxic elements via consumption of vegetables irrigated with polluted river water in Addis Ababa, Ethiopia. Environmental Systems Research, 2019, vol. 8, no. 1, pp. 29. DOI: 10.1186/s40068-019-0157-x

20. U.S. Environmental Protection Agency Risk Characterization Handbook, EPA 100-B-00-002. Science Policy Council U.S. Environmental Protection Agency Washington, DC 20460 Publ., 2000, 189 p.

21. Khan S., Lin A., Zhang S., Hu Q.H., Zhu Y.G. Accumulation of polycyclic aromatic hydrocarbons and heavy metals in lettuce grown in the soils contaminated with long-term wastewater irrigation. Journal of Hazardous Materials, 2008, vol. 152, no. 2, pp. 506-515. DOI: 10.1016/j.jhazmat.2007.07.014

22. EPA Region 9 (Pacific Southwest). USEPA (U.S. Environmental Protection Agency), 2002. Available at: http://www.epa.Gov/region09/waste/sfund/prg (19.02.2021).

23. Reference dose (RfD): Description and use in health risk assessments, Background Document 1A, Integrated risk information system (IRIS). USEPA (U.S. Environmental Protection Agency), 2013. Available at: http://www.epa.gov/iris/rfd.tm (19.02.2021).

24. Provisional Peer-Reviewed Toxicity Values (PPRTV) for Iron and Compounds (CASRN 7439-89-6). Superfund Health Risk Technical Support Center National Center for Environmental Assessment Office of Research and Development U.S. Environmental Protection Agency Cincinnati, OH 45268, 2008, $44 \mathrm{p}$.

25. USEPA (U.S. Environmental Protection Agency Integrated Risk Information System (IRIS) on Arsenic. Arsenic, inorganic (CASRN7440-38-2). USEPA (U.S. Environmental Protection Agency), 1998. Available at: http://www.epa.gov /iris/subst/0278.htm (19.02.2021). 
26. Solutions to Analytical Chemistry Problems with Clean Water Act Methods. Washington, DC, USEPA, 2007, 62 p.

27. Christian G.D., Analytical Chemistry, $6^{\text {th }}$ edition. New York, John Wiley and Sons Publ., 2003, 128 p.

28. Temminghoff E.J., Houba V.J. Plant Analysis Procedures Second Edition. Netherlands, Kluwer Academic Publishers Publ., 2004, 180 p.

29. National Functional Guidelines for Superfund Organic Methods Data Review. Washington, DC, USEPA Publ., 2008, 250 p.

30. Csuros M., Csuros C. Environmental sampling and analysis of metals. USA, CRC Press Publ., 2002, 404 p.

31. Parsons M.L., Forster A.L. Trace Element Determination by Atomic Spectroscopic Methods State of the Art. Applied Spectroscopy, 1983, vol. 37, pp. 411-418. DOI: 10.1366/0003702834634857

32. Tamiru A.A., Hameed S., Amare H. Metal Concentration in Vegetables Grown in the Hydrothermally Affected Area in Ethiopia. Journal of Geography \& Geology, 2011, vol. 3, no. 1, pp. 8. DOI: 10.5539/jgg.v3n1p86

33. Alemayehu T. Heavy metal concentration in the urban environment of Addis Ababa Ethiopia. Journal of Soil and sediment contamination, 2006, vol. 15, no. 6, pp. 591-602. DOI: $10.1080 / 15320380600959081$

34. Report of the 33rd session of the codex committee on food additives and contaminants. The Netherlands, Joint FAO/WHO food standards programme. Codex Alimentarius commission, 2001, 300 p.

35. Risk-based concentration table. Washington, DC, USEPA (United State Environmental Protection Agency) Publ., 2010, 11 p.

36. Mensah E., Allen H.E., Shoji R., Odai S.N., Kyei-Baffour N., Ofori E., Mezler D. Cadmium $(\mathrm{Cd})$ and lead $(\mathrm{Pb})$ concentrations effect on yields of some vegetables due to uptake from irrigation water in Ghana. International Journal of Agricultural Research, 2008, vol. 3, no. 4, pp. 243-251. DOI: 10.3923/ijar.2008.243.251

37. Othman O.C. Heavy metals in green vegetables and soils from vegetable gardens in Dar es Salaam, Tanzania. Tanzania Journal of Science, 2001, vol. 27, no. 1, pp. 37-48. DOI: 10.4314/tjs.v27i1.18334

38. Nazif W., Perveen S., Shah S.A. Evaluation of irrigation water for heavy metals of Akbarpura area. Journal of Agricultural and Biological Science, 2006, vol. 1, pp. 51-54.

39. Report of the thirty-ninth session of the codex committee on food hygiene. New Delhi, Joint FAO/WHO food standards programme Codex Alimentarius commission, 2008, $104 \mathrm{p}$.

40. Guidelines for Drinking Water Quality, $3^{\text {rd }}$ edition. World health organization, 2008, $668 \mathrm{p}$.

41. Kim M.H., Kim J.S., Sho Y.S., Chung S.Y., Lee J.O. Contents of toxic metals in fruits available on Korean markets. Korean Journal of Food Science and Technology, 2004, vol. 36, no. 4, pp. 523-526.

42. Jolaoso A.O., Njoku K.L., Akinola M.O., Adeola A.A. Heavy metal analyses and nutritional composition of raw and smoked fishes from Ologe and Lagos Lagoon, Lagos, Nigeria. Journal of Applied Sciences and Environmental Management, 2016, vol. 20, no. 2, pp. 277-285. DOI: 10.4314/jasem.v20i2.7

43. Divrikli U., Horzum N., Soylak M., Elci L. Trace Heavy Metal Contents of Some Spices and Herbal Plants from Western Anatolia, Turkey. International Journal of Food Science Technology, 2006, vol. 41, no. 6, pp. 712-716. DOI: 10.1111/j.1365-2621.2005.01140.x

44. Doherty V.F., Sogbanmu T.O., Kanife U.C., Wright C. Heavy Metals in Vegetables collected from elected Farm and Market sites in Lagos, Nigeria. Global Advanced Research Journal of Environmental Science and Toxicology's, 2012, vol. 1, no. 6, pp. 137-142.

45. Jabeen S., Shah M.T., Khan S., Qasim M. Determination of Major and Trace Elements in Ten Important Folk Therapeutic Plants of Haripur Basin. Journal of medicinal plant research, 2010, vol. 4, no. 7, pp. 559-566.

46. Khan M.A., Ahmad I., Inayatur R. Effect of environmental pollution on heavy metals content of Withania somnifera. Journal of the Chinese Chemical Society, 2007, vol. 54, pp. 339-343. DOI: $10.1002 /$ jccs. 200700049

47. Davies B.E. Cadmium in Heavy Metals in Soil. Glasgow, Blackie Publ., 1990, 100 p.

48. Girmaye B.R. Heavy metal and microbial contaminants of some vegetables irrigated with wastewater in selected farms around Adama town, Ethiopia. MSc. Graduate project. Haramaya, Haramaya University Publ., 2012, 12 p. 
49. Kalagbor I., Diri E. Evaluation of Heavy Metals in Orange, Pineapple, Avocado Pear, and Pawpaw from a Farm in Kaani, Bori, Rivers State Nigeria. International Research Journal of Public and Environmental Health, 2014, vol. 1, no. 4, pp. 87-94.

50. Khan S.A., Khan L., Hussain I., Marwat K.B. Profile of Heavy Metals in Selected Medicinal Plants. Pakistan Journal of Weed Science Research, 2008, vol. 14, no. 1-2, pp. 101-110.

51. Ata S., Tayyab S., Rasool A. Analysis of Non-volatile Toxic Heavy Metals $(\mathrm{Cd}, \mathrm{Pb}, \mathrm{Cu}, \mathrm{Cr}$, and $\mathrm{Zn}$ ) in Allium sativum (Garlic) and Soil Samples Collected from Different Locations of Punjab, Pakistan by Atomic Absorption Spectroscopy. E3S Web of Conferences, 2013, no. 16004, pp. 1-3. DOI: $10.1051 / \mathrm{e} 3$ sconf/20130116004

52. Wierzbicka M. How lead loses its toxicity to plants. Acta Societatis Botanicorum Poloniae, 1995, no. 64, pp. 81-90. DOI: 10.5586/asbp.1995.012

53. Alloway B.J., Ayres C.D. Chemical Principals of environmental pollutions, ( $2^{\text {nd }}$ edition). London, American Society of Agronomy, 1997, pp. 545-567.

54. Tasrina R.C., Rowshon A., Mustafzur A.M.R., Rafqu I., Ali M.P. Heavy metal contamination in vegetables and its growing soil. Environmental Analytical Chemistry, 2015, vol. 2, no. 3, pp. 142-147. DOI: $10.4172 / 2380-2391.1000142$

55. Singh A., Sharma R.K., Agrawal M., Marshall F. Risk assessment of heavy metal toxicity through contaminated vegetables from wastewater irrigated area of Varanasi, India. Tropical Ecology, 2010, vol. 51, pp. 375-387.

56. Evaluation of certain food additives and contaminants. Geneva, World Health Organization, 2004, 109 p.

57. Huang M., Zhou S., Sun B., Zhao Q. Heavy metals in wheat grains: assessment of potential health risk for inhabitants in Kunshan, China. Science of the Total Environment, 2008, vol. 1, no. 405 (1-3), pp. 54-61. DOI: 10.1016/j.scitotenv.2008.07.004

58. Agency for Toxic Substances and Disease Registry. ATSDR. Available at: https://www.atsdr.cdc. gov/az/c.html_(19.02.2021).

Feseha A., Chaubey A.K., Abraha A. Heavy metal concentration in vegetables and their potential risk for human health. Health Risk Analysis, 2021, no. 1, pp. 68-81. DOI: 10.21668/health.risk/2021.1.07.eng

Received: 29.01 .2021

Accepted: 15.03 .2021

Published: 30.03.2021 